\title{
Depletion of intracellular glutathione and increased lipid peroxidation mediate cytotoxicity of hematite nanoparticles in MRC-5 cells ${ }^{\star}$
}

\author{
Mihaela Radu1, Maria Cristina Munteanu1', Sorina Petrache1, Andreea Iren Serban², Diana \\ Dinu1, Anca Hermenean ${ }^{3}$, Cornelia Sima ${ }^{4}$ and Anca Dinischiotu ${ }^{1 凶}$
}

1Department of Biochemistry and Molecular Biology, Faculty of Biology, University of Bucharest, Bucharest, Romania: 2Departament of Preclinical Sciences, Faculty of Veterinary Medicine, University of Agricultural Sciences and Veterinary Medicine, Bucharest, Romania; ${ }^{3}$ Department of Histology, Vasile Goldis Western University of Arad, Arad, Romania; 4Laser Department, National Institute of Laser, Plasma and Radiation Physics, Bucharest-Magurele, Romania

\begin{abstract}
Particles generated from numerous anthropogenic and/ or natural sources, such as crystalline $\mathrm{a}-\mathrm{Fe}_{2} \mathrm{O}_{3}$ nanoparticles, have the potential to damage lung cells. In our study we investigated the effects of these nanoparticles $(12.5 \mu \mathrm{g} / \mathrm{ml})$ on lipid peroxidation and the antioxidative system in MRC-5 lung fibroblast cells following exposure for 24, 48 or $72 \mathrm{~h}$. Exposure to $\mathrm{a}-\mathrm{Fe}_{2} \mathrm{O}_{3}$ nanoparticles increased lipid peroxidation by $81 \%, 189 \%$ and $110 \%$ after 24,48 and $72 \mathrm{~h}$, respectively. Conversely, the reduced glutathione concentration decreased by $23.2 \%$ and $51.4 \%$ after 48 and $72 \mathrm{~h}$ of treatment, respectively. In addition, an augmentation of the activities of superoxide dismutase, catalase, glutathione peroxidase, glutathione transferase and glutathione reductase within the interval between $48-72 \mathrm{~h}$ was noticed. Taking into account that the reduced glutathione level decreased and the malondialdehyde level, a lipid peroxidation product, remained highly increased up to $72 \mathrm{~h}$ of exposure, it would appear that the MRC-5 antioxidant defense mechanisms did not efficiently counteract the oxidative stress induced by exposure to hematite nanoparticles.
\end{abstract}

Keywords: hematite nanoparticles, MRC-5 cells, lipid peroxidation glutathione, antioxidant enzymes

Received: 08 March, 2010; revised: 26 June, 2010; accepted: 16 August, 2010; available on-line: 11 September, 2010

\section{INTRODUCTION}

Human lungs are in permanent contact with the environment, being one of the entry points for natural or anthropogenic nanoparticles, which have at least one dimension smaller than one micrometer. Due to their small dimensions, the nanometer-sized particles can penetrate the lung barrier and enter the human circulatory and lymphatic systems, becoming dispersed in different organs, tissues and cells. The effects of nanoparticles on cellular processes mainly depend on their size, chemical composition, crystallinity, aggregation, including a potential contribution to the development of lung and neurodegenerative diseases (Buzea et al., 2007).

Iron oxides exist in many forms in nature, with magnetite $\left(\mathrm{Fe}_{3} \mathrm{O}_{4}\right)$, maghemite $\left(\gamma-\mathrm{Fe}_{2} \mathrm{O}_{3}\right)$, and hematite $\left(\alpha-\mathrm{Fe}_{2} \mathrm{O}_{3}\right)$ being probably the most common (Cornell \& Schwertmann, 2003). Furthermore, iron and other met- al oxides nanoparticles are constituents of volcanic ash (Yano et al., 1990). In an aqueous medium containing iron complexes magnetite nanoparticles can be synthesized under aerobic conditions in the presence of Actinobacter spp. (Bharde et al., 2005).

Prepared nanoparticles are often used as industrial catalysts (Oberdorster et al., 2005). Their elevated levels at sites surrounding industrial plants and in the gravitation dust sediments of residential agglomeration (Flórián et al., 2003) combined with the dynamics of dust migration across large distances (Buzea et al., 2007) enhance human exposure.

Nanoparticles such as $\mathrm{Fe}_{3} \mathrm{O}_{4}$ (Hernández et al., 2009) or $\mathrm{Fe}_{2} \mathrm{O}_{3}$ (Sevilla et al., 2009) were used previously for the preparation of efficient magnetic nanocomposites for de-contamination of persistent organic pollutants and arsenic (Giasuddin et al., 2007). All three forms of iron oxide are also used in synthetic pigments in paints, ceramics, and porcelain (Cornell \& Schwertmann, 2003).

Unintentional inhalation due to air pollution or application of products containing iron nanoparticles, as well as unavoidable exposure in the workplace, can generate cellular responses in lungs and other organs that may cause significant public health problems (Donaldson et al., 2005; Powell \& Kanarek, 2006).

The pathways involved in the internalization of nanoparticles into cells are: clathrin-mediated transport (Stearns et al., 2001), caveolae-dependent endocytosis (Mühlfeld et al., 2008), macropinocytotic uptake (Shukla et al., 2005), as well as other mechanisms in which adhesive interactions due to electrostatic forces, Van der Waals or steric interactions (Green et al., 2000, RothenRutishauser et al., 2007) are involved. Once they enter human cells, iron oxide nanoparticles induce reactive oxygen species (ROS) production (Apopa et al., 2009) and oxidative stress.

According to Klotz and Sies (2009), nanoparticles can generate ROS by different mechanisms. Consequently, the uptaken metal oxide nanoparticles can lose the me-

ॠ e-mail: dinischiotu@yahoo.com; adin@bio.unibuc.ro

* The present work was accepted as poster presentation at IUTOX 2010 Barcelona, 19-23 July.

Abbreviations: CAT, catalase; CDNB, 1-chloro-2, 4-dinitrobenzene; $\mathrm{GR}$, glutathione reductase; GPX, glutathione peroxidase; GSH, reduced glutathione; GST, glutathione-S-transferase; MDA, malondialdehyde; MEM, modified Eagle's medium; MTT, 3-(4, 5-dimethylthiazol-2-yl)-2,5-diphenyltetrazolium bromide; ROS, reactive oxygen species; SOD, superoxide dismutase 
tallic ions. Iron, being a highly redox-active transition metal, can be involved in the Fenton reaction producing hydroxyl radicals. These nano-sized particles could directly interact with NADPH oxidases from the plasma membrane and/or mitochondria thus disturbing the electron transport chain and generating a superoxide anion. It is also possible that the nanoparticle-induced damage of the mitochondria and endoplasmic reticulum could determine $\mathrm{Ca}^{2+}$ release into the cytosol, where several $\mathrm{Ca}^{2+} /$ calmodulin dependent enzymes, such as nitrogen monoxide synthase isoforms, become activated, resulting in production of nitric oxide and peroxynitrite.

Both in vitro and in vivo studies of the health effects of ambient nano-materials have identified the generation of oxidative stress as one of the major mechanisms by which air pollution particles exert adverse biological effects.

Cellular redox homeostasis is carefully maintained by an elaborate antioxidant defense system which includes antioxidant enzymes, proteins, and low-molecular-mass scavengers. Excessive ROS production or weakening of antioxidant defense could lead to oxidative stress. Oxidative stress is a redox disequilibrium in which ROS and lipid radicals attack proteins and nucleic acids, redox-sensitive signaling cascades being activated ( $\mathrm{Li}$ et al., 2003). The late cellular response is represented by pro-inflammatory effects (Jeng \& Swanson, 2006) and cytotoxicity (Nel et al., 2006).

The aim of this study was to evaluate the oxidative stress mechanisms induced by $\alpha-\mathrm{Fe}_{2} \mathrm{O}_{3}$ nanoparticles in human lung fibroblast cell line MRC-5. The malondialdehyde (MDA) and reduced glutathione (GSH) levels as well as the activities of antioxidant enzymes, such as superoxide dismutase (SOD), catalase (CAT), glutathione peroxidase (GPX), glutathione reductase (GR) and glutathione-S-transferase (GST) were also analyzed.

\section{MATERIALS AND METHODS}

Chemicals. GIBCO ${ }^{\circledR}$ Modified Eagle's Medium (MEM), fetal bovine serum, gentamycin $(10 \mathrm{mg} / \mathrm{ml}), \mathrm{L}-$ glutamine and vitamin solution $(100 \times)$ were purchased from Invitrogen (Carlsbad, California, USA). Nicotinamide adenine dinucleotide phosphate disodium salt $\left(\mathrm{NADP}^{+}\right)$and nicotinamide adenine dinucleotide phosphate reduced tetrasodium salt (NADPH) were from Merck (Darmstadt, Germany). Tetraethoxypropane (TEP) and thiobarbituric acid (TBA) were obtained from Fluka (Milwaukee, USA). The Detect $\mathrm{X}^{\circledR}$ Glutathione Colorimetric Detection Kit was purchased from Arbor Assay (Michigan, USA). Other chemicals used were of analytical grade and were from Sigma (St. Louis, Missouri, USA).

Nanoparticles. Nanoparticles of the $\alpha$ form of $\mathrm{Fe}_{2} \mathrm{O}_{3}$ (hematite) were obtained by laser reactive ablation in the Laser Department of the National Institute of Laser, Plasma and Radiation Physics (BucharestMăgurele, Romania). The particle size assessment was performed with a high resolution transmission electron microscope (Philips CM120 model). The primary nanoparticle size distribution was lognormal in the range 10-120 nm, most of them measuring 40-60 nm. For crystallinity analysis Bruker AXS/D8 ADVANCE X ray diffractometer was used.

Cell lines and treatment. MRC-5 cells were maintained in MEM containing non-essential amino acids,
Earle's salts, L-glutamine and $10 \%$ fetal bovine serum. Cells, between passages 11-20, were grown as monolayers in a humidified $5 \% \mathrm{CO}_{2}$ air atmosphere at $37{ }^{\circ} \mathrm{C}$ in $75 \mathrm{~cm}^{2}$ culture flasks. They were seeded at a density of $2.5 \times 10^{5}$ cells $/ \mathrm{ml}$. Stock suspensions of $\alpha-\mathrm{Fe}_{2} \mathrm{O}_{3}$ nanoparticles were sterilized before use. In each experiment, the stock suspensions were sonicated and freshly diluted to appropriate concentrations in the cell medium. The cells were incubated with hematite nanoparticles at concentrations of $2.5 \mu \mathrm{g} / \mathrm{ml}, 6.25 \mu \mathrm{g} /$ $\mathrm{ml}$, or $12.5 \mu \mathrm{g} / \mathrm{ml}$ in the culture medium for 24,48 , and $72 \mathrm{~h}$. Controls without treatment were performed for each experiment.

Cell viability assay. The viability of the cells was determined by the tetrazolium salt test (Mosmann, 1983). The medium from each well was removed by aspiration, the cells were washed with $200 \mu$ l of phosphate-buffered saline (PBS)/well and then $50 \mu \mathrm{l}$ $(1 \mathrm{mg} / \mathrm{ml})$ of 3 -(4, 5-dimethylthiazol-2-yl)-2,5-diphenyltetrazolium bromide (MTT) solution was added to each well. After $2 \mathrm{~h}$ of incubation the MTT solution from each well was removed by aspiration. A volume of $50 \mu \mathrm{l}$ isopropanol was added and the plate was shaken to dissolve the formazan crystals. The absorbance at $595 \mathrm{~nm}$, was then determined using a Tecan multiplate reader (Tecan GENios, Grödic, Germany), for each well. The absorbance for untreated cells was taken to represent the $100 \%$ viability.

Preparation of cell lysate. MRC-5 cells were harvested from culture flasks, after the removal of medium which contained the floating dead cells, washed with PBS and centrifuged at $1500 \times g$ for $10 \mathrm{~min}$ at $4^{\circ} \mathrm{C}$. Cell pellets were re-suspended in $0.5 \mathrm{ml}$ of PBS and then sonicated on ice three times, for $30 \mathrm{~s}$ each. The total extract was centrifuged at $3000 \times g$ for 15 $\min$ at $4{ }^{\circ} \mathrm{C}$. Aliquots of the supernatant were used for enzyme assays.

Lipid peroxidation. MDA, as an in vitro marker of lipid peroxidation, was assessed by a method described by Del Rio et al. (2003). To $200 \mu \mathrm{l}$ of sample with a protein concentration of $2 \mathrm{mg} / \mathrm{ml}, 700 \mu \mathrm{l}$ of $0.1 \mathrm{M} \mathrm{HCl}$ was added and the mixture was incubated for $20 \mathrm{~min}$ at room temperature. Then, $900 \mu \mathrm{l}$ of $0.025 \mathrm{M}$ thiobarbituric acid (TBA) was added and the mixture was incubated for $65 \mathrm{~min}$ at $37^{\circ} \mathrm{C}$. Finally, $400 \mu \mathrm{L}$ of $10 \mathrm{mM}$ PBS was added. The fluorescence of MDA was recorded using a 520/549 (excitation/emission) filter. A calibration curve with MDA in the range $0.05-5 \mu \mathrm{M}$ was used to calculate the MDA concentration. The results were expressed as nmoles of $\mathrm{MDA} / \mathrm{mg}$ protein.

Glutathione assay. The cellular lysate, deproteinized with $5 \%$ sulfosalicylic acid, was analyzed for total glutathione and oxidized glutathione (GSSG) using the Detect $\mathrm{X}^{\circledR}$ Glutathione colorimetric detection kit and following manufacturer's instructions. GSH concentration is obtained by subtracting the GSSG level from the total glutathione. The total and GSH levels were calculated as nmoles/mg protein.

Antioxidant enzymes assay. Total SOD (EC 1.15.1.1) activity was measured according to the spectrophotometric method of Paoletti et al. (1986), based on NADPH oxidation by the superoxide anion generated from molecular oxygen by a purely chemical reaction in the presence of EDTA, manganese (II) chloride and mercaptoethanol. The decrease in absorbance at $340 \mathrm{~nm}$ due to NADPH oxidation was followed for $10 \mathrm{~min}$. A control was run with each set of three duplicate samples and the percent inhibition was calculated as (sample 
rate $) /($ control rate $) \times 100$. One unit $(U)$ of activity was defined as the amount of enzyme required to inhibit the rate of NADPH oxidation of the control by $50 \%$.

The CAT (EC 1.11.1.6) activity was assayed by monitoring the disappearance of $\mathrm{H}_{2} \mathrm{O}_{2}$ at $240 \mathrm{~nm}$, according to the method of Aebi (1984). The CAT activity was calculated in terms of $\mathrm{U} / \mathrm{mg}$ protein, where one unit (U) is the amount of enzyme catalyzing the conversion of one $\mu$ mole of $\mathrm{H}_{2} \mathrm{O}_{2}$ in a minute under standard condition of temperature, optimal $\mathrm{pH}$ and optimal substrate concentration.

Total GPX (EC 1.11.1.9) was assayed by the Beutler method (1971), using tert-butyl hydroperoxide and NADPH as substrates. The conversion of NADPH to $\mathrm{NADP}^{+}$was followed by recording the changes in absorbance at $340 \mathrm{~nm}$, and the concentration of NADPH was calculated using a molar extinction coefficient of $6.22 \times 10^{3} \mathrm{M}^{-1} \cdot \mathrm{cm}^{-1}$. The activity was expressed as $\mathrm{U} / \mathrm{mg}$. One unit of activity was defined as the amount of enzyme that catalyzes the conversion of one $\mu$ mole of NADPH per minute under standard conditions.

The GR (EC 1.6.4.2) activity was measured according to the method of Goldberg and Spooner (1983), in $0.1 \mathrm{M}$ phosphate buffer, $\mathrm{pH} 7.4$ with $0.66 \mathrm{mM}$ GSSG and $0.1 \mathrm{mM}$ NADPH by recording the decrease of absorbance at $340 \mathrm{~nm}$. The activity of this enzyme was expressed as $\mathrm{U} / \mathrm{mg}$, one unit of GR activity been defined as one $\mu$ mole of NADPH per minute under standard conditions.

The GST (EC 2.5.1.18) activity was assayed spectrophotometrically at $340 \mathrm{~nm}$ by measuring the rate of CDNB conjugation with GSH, according to the method of Habig et al. (1974), and calculated as $\mathrm{U} / \mathrm{mg}$. One unit of GST activity was defined as the amount of enzyme that catalyzed the transformation of one $\mu$ mole of $\mathrm{CDNB}$ in conjugated product per minute. The extinction coefficient $9.6 \times 10^{3} \mathrm{M}^{-1} \cdot \mathrm{cm}^{-1}$ was used for the calculation of CDNB concentration.

All enzymatic activities, calculated as specific activities (units/mg protein) are expressed as percentage of controls.

Protein concentration. The protein concentration $(\mathrm{mg} / \mathrm{ml})$ was determined by the method of Bradford (1976), using bovine serum albumine as a standard.

Statistical analysis. The differences between control and $\alpha-\mathrm{Fe}_{2} \mathrm{O}_{3}$ nanoparticles-treated cells were compared by Student's $t$-test using standard statistical packages. All data were expressed as means $(n=4) \pm$ standard deviation (S.D.) and differences were considered significant from control at $P<0.05$, highly significant at $P<0.01$ and extremely significant at $P<0.001$.

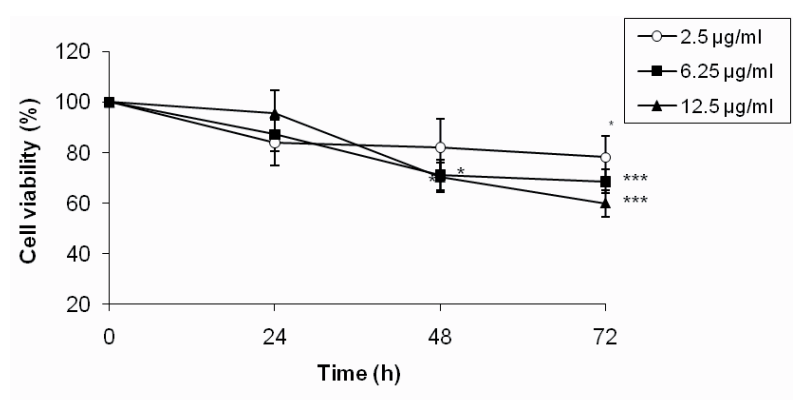

Figure 1. Viability of MRC-5 cells following exposure to $a-\mathrm{Fe}_{2} \mathrm{O}_{3}$ nanoparticles

The values shown are means \pm S.D. $(n=6)$ and expressed as percentage of time-interval controls ${ }^{*} P<0.05 ;{ }^{* * *} P<0.001$.

\section{RESULTS}

\section{Cell viability}

The hematite nanoparticles decreased the number of viable MRC-5 cells in a time- and dose-dependent manner (Fig. 1). The incubation of cells with $2.5 \mu \mathrm{g} / \mathrm{ml}$ of $\alpha-\mathrm{Fe}_{2} \mathrm{O}_{3}$ did not cause a significant loss of viability after $24 \mathrm{~h}$ or $48 \mathrm{~h}$, and a decrease by $22 \%$ after $72 \mathrm{~h}$. The decrease in cell viability induced by the exposure to $6.25 \mu \mathrm{g} / \mathrm{ml} \alpha-\mathrm{Fe}_{2} \mathrm{O}_{3}$ was between $29 \%$ after $48 \mathrm{~h}$ and $31.5 \%$ after $72 \mathrm{~h}$. After the treatment of MRC-5 cells with the highest $\alpha-\mathrm{Fe}_{2} \mathrm{O}_{3}$ concentration of $12.5 \mu \mathrm{g} / \mathrm{ml}$, the viability decreased by $10 \%$ after $24 \mathrm{~h}$, and by $30 \%$ and $44 \%$ after $48 \mathrm{~h}$ and $72 \mathrm{~h}$, respectively.

Taking into account that the most pronounced effects were noticed at the highest concentration tested $(12.5 \mu \mathrm{g} /$ $\mathrm{ml})$, this was used in all subsequent experiments.

\section{Lipid peroxidation}

The exposure of MRC-5 cells to hematite nanoparticles increased the MDA concentration in a time-dependent manner by $81 \%, 189 \%$ and $110 \%$ after 24,48 and $72 \mathrm{~h}$, respectively (Table 1). As it can be seen in Table 1 , the MDA level continuously increased in the first $48 \mathrm{~h}$ of exposure and started decreasing after $72 \mathrm{~h}$, but still remained high in comparison with control.

\section{Total and reduced glutathione depletion}

The results shown in Table 1 indicate that exposure of MRC-5 cells to $\mathrm{Fe}_{2} \mathrm{O}_{3}$ nano-sized particles resulted in a slight diminution in the total glutathione level by $17.7 \%$ after $48 \mathrm{~h}$, followed by a decline by $51.4 \%$ after $72 \mathrm{~h}$. The same tendency was noticed for the GSH con-

Table 1. Lipid peroxidation, total glutathione and GSH concentrations in MRC-5 cells after treatment with $12.5 \mu \mathrm{g} / \mathrm{mL} \mathrm{a-Fe} \mathrm{O}_{3}$ Values are means \pm S.D. $(n=4)$

\begin{tabular}{|c|c|c|c|c|}
\hline $\begin{array}{l}\text { Time } \\
\text { (hours) }\end{array}$ & Sample & Total glutathione (nmoles/mg) & GSH (nmoles/mg) & Lipid peroxidation (nmoles MDA/mg) \\
\hline \multirow[t]{2}{*}{24} & Control & $25.62 \pm 0.36$ & $23.23 \pm 0.11$ & $0.021 \pm 0.004$ \\
\hline & a-Fe2O3 nanoparticles & $26.57 \pm 0.34$ & $22.65 \pm 0.17$ & $0.038 \pm 0.002^{*}$ \\
\hline \multirow[t]{2}{*}{48} & Control & $30.67 \pm 0.17$ & $27.82 \pm 0.18$ & $0.019 \pm 0.004$ \\
\hline & $\mathrm{a}-\mathrm{Fe}_{2} \mathrm{O}_{3}$ nanoparticles & $25.24 \pm 0.28^{* *}$ & $21.35 \pm 0.26^{* *}$ & $0.055 \pm 0.002^{* * * *}$ \\
\hline \multirow[t]{2}{*}{72} & Control & $31.52 \pm 0.12$ & $25.32 \pm 0.33$ & $0.020 \pm 0.002$ \\
\hline & $\mathrm{a}-\mathrm{Fe}_{2} \mathrm{O}_{3}$ nanoparticles & $15.23 \pm 0.17^{* * *}$ & $12.24 \pm 0.29^{* * *}$ & $0.042 \pm 0.003^{* * * *}$ \\
\hline
\end{tabular}

${ }^{*} P<0.05 ;{ }^{* *} P<0.01 ;{ }^{* *} P<0.001$. 

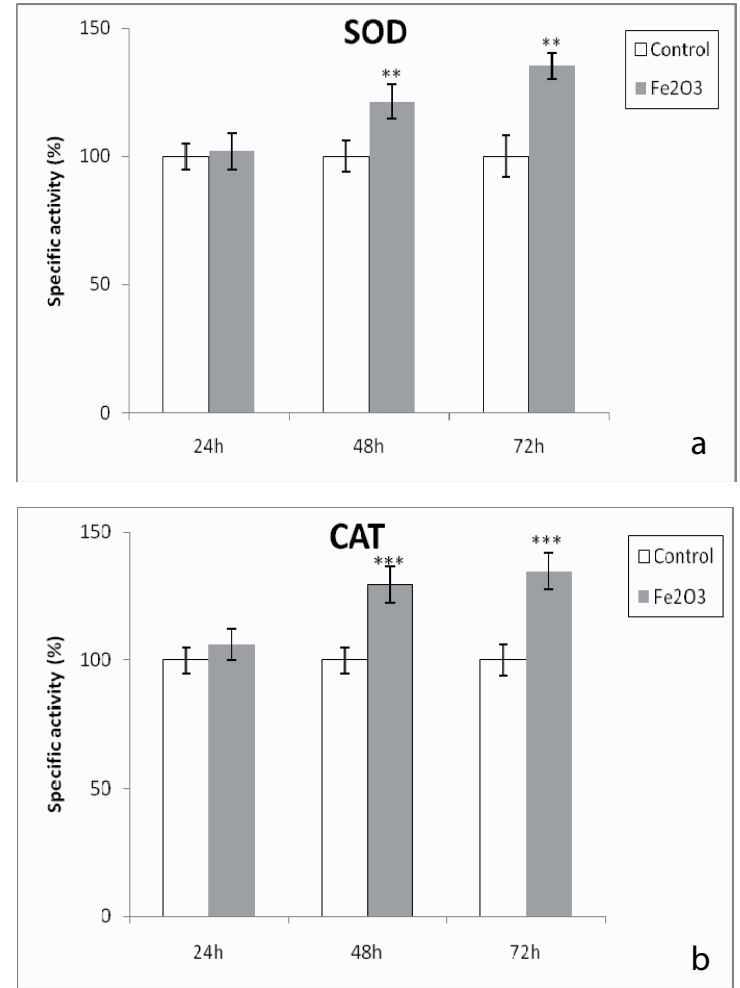

Figure 2. Effects of exposure to a-Fe $\mathrm{O}_{2}$ nanoparticles on the activities of SOD (a) and CAT (b) in MRC-5 cells

The values are calculated as means \pm S.D. $(n=4)$ and expressed as percentage of controls. ${ }^{* *} P<0.01$; $^{* * *} P<0.001$.

tent which decreased by $23.2 \%$ and $51.4 \%$ after $48 \mathrm{~h}$ and $72 \mathrm{~h}$ of treatment, respectively.

\section{The antioxidant scavenging enzymes}

Figures $2 \mathrm{a}$ and $2 \mathrm{~b}$ show the effects of $\alpha-\mathrm{Fe}_{2} \mathrm{O}_{3}$ nanoparticles on the activities of antioxidant enzymes, SOD and CAT in MRC-5 cells. The SOD activity increased by $21.2 \%$ and $35.1 \%$ after $48 \mathrm{~h}$ and $72 \mathrm{~h}$, and for the same time points, the activity of CAT was up-regulated by $29.5 \%$ and $34.7 \%$, respectively; however, no significant changes were noticed after $24 \mathrm{~h}$.

After $24 \mathrm{~h}$ of exposure to hematite nanoparticles, no significant changes of the specific activities of GPX, GR and GST were visible.

Beginning at $48 \mathrm{~h}$ of exposure, an increase in GPX, GR and GST activities was noticed (Figs. 3a, 3b, 3c): by $52 \%$ and $37 \%$ for GPX activity, by $21 \%$ and $32 \%$ for GST, and by $13 \%$ and $21 \%$ for GST after $48 \mathrm{~h}$ and $72 \mathrm{~h}$ of treatment, respectively.

\section{DISCUSSION}

This study was initiated in order to evaluate the antioxidative capacity of MRC-5 lung fibroblasts exposed to hematite nanoparticles, taking into account that human occupational and environmental exposures to these is common. In our study, nanoparticles between $40 \mathrm{~nm}$ and $60 \mathrm{~nm}$ were dominated in the preparation used. Such particles have high coefficient of diffusion leading to efficient deposition probability at airways bifurcation and centers of lung acini (Churg \& Vedal, 1996), before they
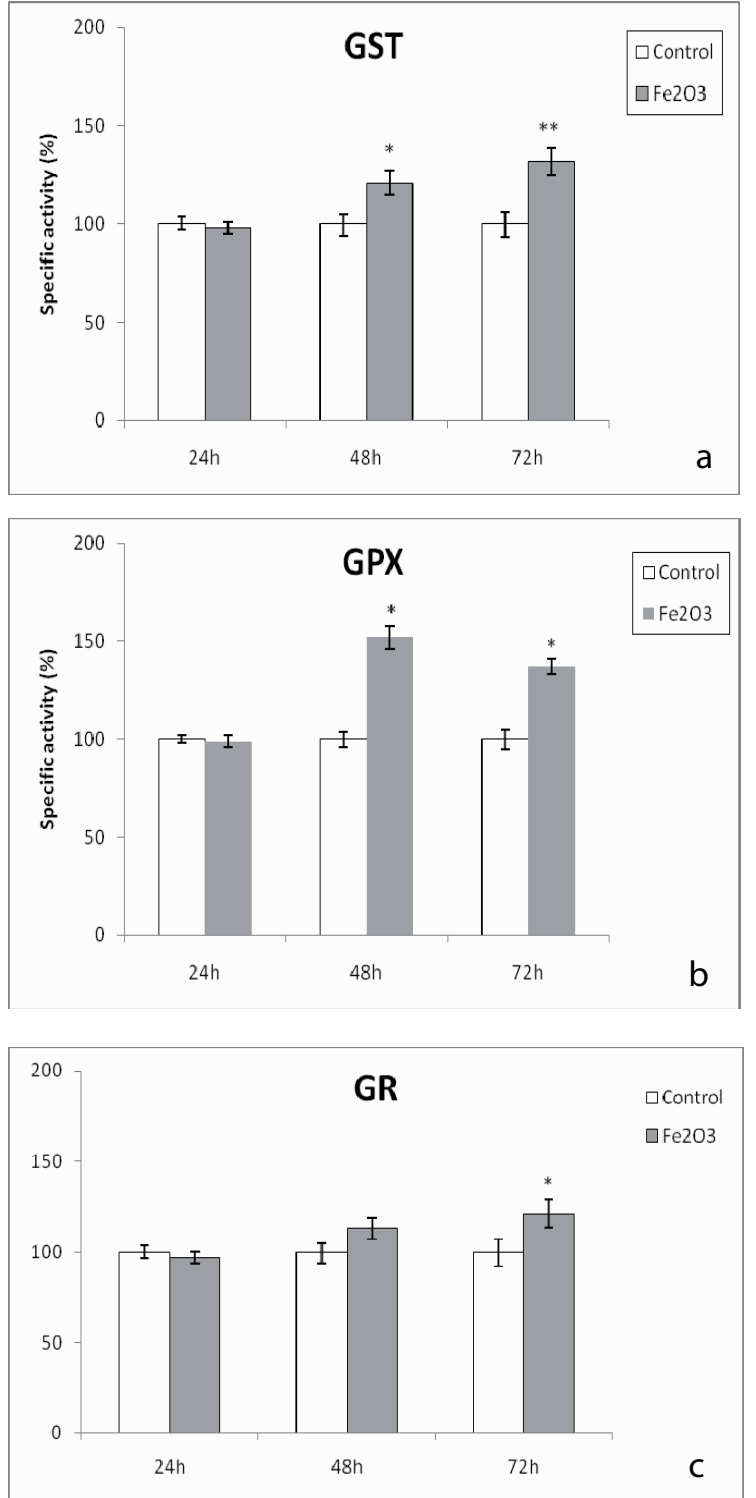

Figure 3. Effects of exposure to $\mathrm{a}-\mathrm{Fe}_{2} \mathrm{O}_{3}$ nanoparticles on GST (a) and GPX (b) and GR (c) activities in MRC-5 cells

The values are means $\pm S . D$. $(n=4)$ and expressed as percentage of controls. ${ }^{*} P<0.05 ;{ }^{* *} P<0.01$.

are transported to the deep lung (Maynard \& Kuempel, 2005).

Hematite is insoluble at a physiological temperature and $\mathrm{pH}$ (Diakonov et al., 1999), but interfacial hydration of anhydrous hematite results in higher solubility (Jang et al., 2007). On the other hand, $\alpha \mathrm{Fe}_{2} \mathrm{O}_{3}$ nanoparticles could release some ferric ions once they enter the cells, as previously noticed for other types of ultrafine particles (Wang et al., 2008). Subsequently, these ions would be able to interact with hydrogen peroxide physiologically formed by different types of enzyme-catalyzed reactions, generating hydroperoxyl radical (Hurd \& Murphy, 2009) according to the reaction:

$\mathrm{Fe}^{3+}+\mathrm{H}_{2} \mathrm{O}_{2} \rightarrow \mathrm{Fe}^{2+}+\mathrm{H}^{+}+\mathrm{HOO}$

Ferrous ions also participate in the Fenton reaction, generating a hydroxyl radical.

Three possible mechanisms have been put forward to explain superoxide anion generation in MRC-5 cells, af- 
ter nano-sized hematite enters the cells. First, the uptaken nanoparticles could interact with NADPH oxidase in the plasma membrane, thus generating superoxide in the extracellular space (Dhaunsi et al., 2004), which would enter the cell through an anion channel (Bedard \& Krause, 2007). Second, these nanoparticles could interact with a recently identified NADPH oxidase isoform located in the endoplasmatic reticulum (Chen et al., 2008), forming this oxygen radical endogenously. And third, small quantities of $\mathrm{Fe}^{3+}$ ions released from these nanoparticles in the cytosol, could be reduced to $\mathrm{Fe}^{2+}$ according to reaction (1) and imported into the mitochondrial matrix through orthologs of Mrs3/Mrs4 transporters (Froschauer et al., 2009) in vertebrates. The mitochondrial iron accumulation appears to be ensued by oxidative damage (Crichton et al., 2002). The labile iron pool present within mitochondria (Kruszewski, 2004) together with the decrease of reduced glutathione level could impair the biogenesis of iron-sulfur clusters within the matrix (Hausmann et al., 2005). These iron-sulfur clusters are present in different mitochondrial proteins including some of the mitochondrial electron transport chain. At the ultrastructural level, Complexes I and III are the main sites of mitochondrial superoxide production. It has been demonstrated that Complex I-dependent superoxide is exclusively released into the matrix whereas Complex III releases superoxide to both sides of the inner mitochondrial membrane (Muller et al., 2004). In Complex I, the most likely sites of electron leakage are the iron sulfur clusters (Barja, 1999).

Several enzymatic defense mechanisms attempt to minimize the production and the action of harmful oxidants, such as SOD, CAT and GPX.

SOD dismutates the free radical superoxide by converting it to hydrogen peroxide, which in turn is decomposed by CAT at high concentration, and by GPX at low concentration. In our experiment, the activities of SOD and CAT increased after $48 \mathrm{~h}$ and remained at almost same levels for the next $24 \mathrm{~h}$. Most hydrogen peroxide in the cell is generated through the dismutation of superoxide by SOD action, even though it can be produced by other superoxidegenerating enzymes (Hauptmann et al., 1996; Arimoto et al., 2005). It was proved that lung edema was markedly supressed by pretreatment with polyethylene glycol-modified superoxide dismutase (Sagai et al., 1993). Probably, the generation of superoxide becomes critical in a time-dependent manner, and so the induction of SOD activity is important only after $48 \mathrm{~h}$ of exposure to hematite nanoparticles. Despite the good correlation between the SOD and CAT activities in MRC-5 cells, some superoxide and hydrogen peroxide could remain in the cells.

The superoxide anions that escape dismutation can react with hydrogen peroxide according to Haber-Weiss reaction to form hydroxyl radicals or become protonated to hydroperoxyl radicals. Hydroperoxyl and hydroxyl radicals are able to abstract hydrogen atom from a methylene group adjacent to double bonds of polyunsaturated fatty acids forming carbon centered radicals that react with molecular oxygen to form lipid peroxides (Antunes et al., 1996). The significant increase of MDA concentration, by $189 \%$ and $110 \%$ after $48 \mathrm{~h}$ and $72 \mathrm{~h}$, respectively, suggests that the antioxidative system adaptation was not sufficient to prevent damage of membrane lipids; in turn, the lipid peroxidation products could affect the structure of DNA bases (Valko et al., 2006), proteins and carbohydrates. Similar results were obtained in human bronchial epithelial BEAS-2B cells exposed to $\mathrm{TiO}_{2}$ nanoparticles (Gurr et al., 2005) and $\mathrm{ZnO}$ ones (Yang et al., 2009) whereas in A549 human lung epithelial cells treated with maghemite nano-sized particles, the change in lipid peroxidation variation was statistically insignificant (Guo et al., 2009).

The enzymes of the glutathione redox cycle, comprising GPX, GR and GST, are another source of protection against oxidative stress. GPX and GST, the enzymes that reduce the levels of peroxides thereby protecting the cell from peroxidative damages, showed similar responses during exposure to $\alpha-\mathrm{Fe}_{2} \mathrm{O}_{3}$ nanoparticles. An activation of GPX was observed, with the maximum at $48 \mathrm{~h}$ of about $152 \%$ compared to the time-interval control; subsequently, the activity of this enzyme decreased to $137 \%$ of the control at $72 \mathrm{~h}$. The decrease in GPX activity could suggest inactivation by ROS, whose level increased in MRC-5 cells after $72 \mathrm{~h}$. Superoxide anions have been shown to inhibit GPX (Blum \& Fridovich, 1985). Accordingly, the antioxidant defense system of MRC-5 cells reacted positively to $\alpha-\mathrm{Fe}_{2} \mathrm{O}_{3}$ nanoparticles toxicity by increasing the GST activity. The family of GSTs contains enzymes that are capable of multiple reactions with a multitude of substrates in order to detoxify the endogenous compounds, such as peroxidised lipids, as well as the metabolism of xenobiotics.

The increase of the GPX and GST activities may be correlated with the observed decrease in GSH content of MRC-5 cells. Thus the decrease in the level of GSH after $48 \mathrm{~h}$ of $\alpha-\mathrm{Fe}_{2} \mathrm{O}_{3}$ nanoparticle treatment may be explained by its use as a substrate of GPX. The increased participation of GSH in conjugation reactions mediated by increased GST activity seems to be a plausible explanation for the reduced GSH content (51.4\% from time interval control) after exposure to $\alpha-\mathrm{Fe}_{2} \mathrm{O}_{3}$ nanoparticles for $72 \mathrm{~h}$. Other noticeable changes concerning the enzymatic antioxidant response to the nanoparticles-linked oxidative stress were registered in the specific activity of GR, an enzyme involved in the recycling of GSSG to GSH. Nevertheless, this enzymatic adaptation was insufficient to prevent the significant reduction of the GSH concentration in MRC- 5 cells after $72 \mathrm{~h}$ of treatment, which suggested an oxidative stress condition. On the other hand, ferric ions at high concentrations, being electrophilic, can deplete intracellular reduced glutathione by interacting with sulfhydryl groups (Brodie et al., 1982) or by inhibition of several cellular activities including the cystine uptake (Bannai, 1984). Also, the long exposure to hematite nanoparticles could induce the loss of cellular GSH by glutathionylation of several proteins (Hare \& Stamler, 2005).

In conclusion, taking into account that the GSH concentration decreased and MDA level remained highly increased up to $72 \mathrm{~h}$ of treatment, it appears that the MRC-5 antioxidant defense mechanisms do not efficiently counteract the oxidative stress induced by exposure to hematite nanoparticles and possible damaging effects could occur.

\section{Acknowledgement}

This study was financially supported by the $\mathrm{Na}$ tional Research Council of Higher Education, Romania, Grant number 340/2007 and Grant POSDRU 8/1.5/S/61150/2010 co-financed from European Social Fund by the Sectorial Operational Program for Development of Human Resources 2007-2013. The authors are grateful to COST B35/2006 Action for the opportunity to exchange ideas with experts in lipid peroxidation and oxidative stress.

\section{REFERENCES}

Aebi H (1984) Catalase in vitro. In Methods of ensymatic analysis. Bergmayer HU, ed, pp 673-684. Weinheim, FRG. 
Antunes F, Salvador A, Marinho HS, Alves R, Pinto RE (1996) Lipid peroxidation in mitochondrial inner membranes. I. An integrative kinetic model. Free Rad Biol Med 21: 917-943.

Apopa PL, Qian Y, Shao R, Lan Guo N, Schwegler-Berry D, Pacurari M, Porter D, Shi X, Vallayathan V, Castranova V, Plynn DC (2009) Iron oxide nanoparticles induce human microvascular endothelial cell permeability through reactive oxygen species production and microtubule remodeling. Part Fibre Toxicol 6: 1.

Arimoto T, Kadiiska MB, Sato K, Corbett J, Mason RP (2005) Synergistic production of lung free radicals by diesel exhaust particles and endotoxin. Am J Respir Crit Care Med 171: 379-387.

Bannai S (1984) Transport of cystine and cysteine in mammalian cells. Biocbim Biophys Acta 779: 289-306.

Barja G (1999) Mitochondrial oxygen radical generation and leak: sites of production in states 4 and 3 , organ specificity and relation to aging and longevity. J Bioenerg Biomembr 31: 347-366.

Bedard K, Krause KH (2007) The NOX family of ROS-generating NADPH oxidases: physiology and pathophysiology. Physiol Rev 87: 245-313.

Beutler E (1971) Red cell metabolism. In A manual of biochemical methods, eds, pp 71-73. Grune \& Stratton, New York.

Bharde A, Wani A, Shouche J, Joy PA, Prasad BL, Sastry S (2005) Bacterial aerobic synthesis of nanocrystalline magnetite. J Am Chem Soc 127: 9326-9327.

Blum J, Fridovich I (1985) Inactivation of glutathione peroxidase by superoxide radical. Arch Biochem Biophys 240: 500-508.

Bradford MM (1976) A rapid and sensitive method for the quantitation of microgram quantities of protein utilizing the principle of proteindye binding. Anal Biochem 72: 248-254.

Brodie AE, Potter J, Reed DJ 1(982) Unique characteristics of rat spleen lymphocyte, L1210 lymphoma and HeLa cells in glutathione biosynthesis from sulfur-containing amino acids. Eur J Biochem 123: $159-164$

Buzea C, Pacheco II, Robbie K (2007) Nanomaterials and nanoparticles: sources and toxicity. Biointerphases 2: MR17-MR71.

Chen K, Kirber MT, Xiao H, Yang Y, Keaney JF Jr (2008) Regulation of ROS signal transduction by NADPH oxidase 4 localization. J Cell Biol 181: 1129-1139.

Churg A, Vedal S (1996) Carinal and tubular airway particle concentrations in the large airways of non-smokers in the general population: Evidence for high particle concentration at airways carinas. Occup Environ Med 53: 553-558.

Cornell RM, Schwertmann U (2003) The iron oxides: Structure, properties, reactions, occurrences and uses, pp 2-3. Wiley-VCH Verlag, Weinheim, Germany.

Crichton RR, Wilmet S, Legssyer R, Ward RJ (2002) Molecular and cellular mechanisms of iron homeostasis and toxicity in mammalian cells. J Inorg Biochem 91: 9-18.

Del Rio D, Pellegrini N, Colombi B, Bianchi M, Serafini M, Torta F, Tegoni M, Musci M, Brighenti F (2003) Rapid fluorimetric method to detect total plasma malondialdehyde with mild derivatization conditions. Clin Chem 49: 690-692.

Dhaunsi G, Paintlia MK, Kauer J, Turner R (2004) NADPH oxidase in human lung fibroblasts. J Biomed Sci 11: 617-622.

Diakonov I, Schott J, Martin F, Harrichourry J-C, Escalier J (1999) Iron (III) solubility and speciation in aqueous solutions. Experimental study and modeling: Part I. Hematite solubility from 60 to $300^{\circ} \mathrm{C}$ in $\mathrm{NaOH}-\mathrm{NaCl}$ solutions and thermodynamic properties of $\mathrm{Fe}(\mathrm{OH})_{4}$. Geochim Cosmochim Acta 63: 2247-2261.

Donaldson K, Tran L, Jimenez LA, Duffin R, Newby DE, Mills N, MacNee W, Stone V (2005). Combustion-derived nanoparticles: A review of their toxicology following inhalation exposure. Part Fibre Toxicol 2: 10 .

Flórián K, Matherny M, Nickel H, Pliešovská N, Uhrinová K (2003), Environmental characteristics of the atmosphere of residential agglomerations. II. Main, minor and trace elements in the gravitation dust sediments. Chem Pap 57: 374-381.

Froschauer EM, Schweyen RJ, Wiesenberger G (2009) The yeast mitochondrial carrier proteins Mrs3p/Mrs4p mediate iron transport across the inner mitochondrial membrane. Biochim Biophys Acta, 1788: 1044-1050.

Giasuddin ABM, Kanel SR, Choi H (2007) Adsorption of humic acid onto nanoscale zerovalent iron and its effect on arsenic removal. Environ Sci Technol 41: 2022-2027.

Goldberg DM, Spooner RJ (1983) Glutathione reductase. In Methods of ensymatic analysis, 3rd ed. Bergmayer HU, ed, pp 258-265. Dearfield Beach: Verlag Chemie.

Green FHY, Gehr P, Lee MM, Schürch S (2000) The role of surfactant in disease associated with particle exposure. In Particle-Lung Interactions. Gehr P, Heyder J, eds, pp 533-572. Marcel Dekker Inc, New York.

Guo B, Zebda R, Drake SJ, Sayes CM (2009) Synergistic effect of co-exposure of carbon black and $\mathrm{Fe}_{2} \mathrm{O}_{3}$ nanoparticles on oxidative stress in cultured lung epithelial cells. Part Fibre Toxicol 6: 4.
Gurr JR, Wang AS, Chen CH, Jan KY (2005) Ultrafine titanium dioxide particles in the absence of photoactivation can induce oxidative damage to human bronchial epithelial cells. Toxicology 213: 66-73.

Habig WH, Pabst MJ, Jakoby WB (1974) Glutathione- $S$-transferase. The first enzymatic step in mercapturic acid formation. J Biol Chem 249: 7130-7139.

Hare JM, Stamler JS (2005) NO/redox disequilibrium in the failing heart and cardiovascular system. I Clin Invest 115: 509-517.

Hauptmann N, Grimsby J, Shih JC, Cadenas E (1996) The metabolism of tyramine by monoamine oxidase $\mathrm{A} / \mathrm{B}$ causes oxidative damage to mitochondrial DNA. Arch Biochem Biophys 335: 295-304.

Hausmann A, Aguilar Netz DJ, Balk J, Pierik AJ, Muhlerhoff U, Lill R (2005) The eukaryotic P loop NT-Pase Nbp35: an essential component of the cytosolic and nuclear iron-sulfur protein assembly machinery. Proc Natl Acad Sci USA 102: 3266-3271.

Hernández R, Zamora-Mora V, Sibaja-Ballestera M, Vega-Baudrit J, López D, Myangos C (2009) Influence of iron oxide nanoparticles on the rheological properties of hybrid chitosan ferrogels. J Colloid Interface Sci 339: 53-59.

Hurd TR, Murphy MP (2009) Biological systems relevant for redox signalling and control. In Redox signalling and regulation in biology and medicine. Jacob C, Winyard PG, eds, pp 13-45. Wiley-VCH Verlag GmbH\&Co. KGaA, Weinheim.

Jang J-H, Dempsey B, Burgos W (2007) Solubility of hematite revisited: Effects of hydration. Environ Sci Technol 41: 7303-7308.

Jeng HA, Swanson J (2006) Toxicity of metal oxide nanoparticles in mammalian cells. J Environ Sci Health 41: 2699-2711.

Klotz LO, Sies H (2009) Cellular generation of oxidants: relation to oxidative stress. In Redox signaling and regulation in biology and medicine. Jacob C, Winyard PG, eds, pp 45-61. Wiley-VCH Verlag, Weinheim, Germany.

Kruszewski M (2004) The role of labile iron pool in cardiovascular diseases. Acta Biocbim Pol 51: 471-480.

Li N, Hao M, Phalen RF, Hhinds WC, Nel AE (2003) Particulate air pollutants and asthma. A paradigm for the role of oxidative stress in PM-induced adverse health effects. Clin Immunol 109: 250-265.

Maynard AD, Kuempel ED (2005) Airborne nanostructured particles and occupational health. J Nanopart Res 7: 587-614.

Mosmann J (1983) Rapid colorimetric assay for cellular growth and survived. J Immunol Methods 65: 55-63.

Muller FL, Liu Y, Van Remmen H (2004) Complex III releases superoxide to both sides of the inner mitochondrial membrane. J Biol Chem 279: 49064-49073.

Múhlfeld C, Rothen-Rutishauser B, Blank F, Vanhecke D, Ochs M, Gehr P (2008) Interactions of nanoparticles with pulmonary structures and cellular responses. Am J Physiol Lung Cell Mol Physiol 294: L817-L829.

Nel A, Xia T, Madler L, Li N (2006) Toxic potential of materials at the nanolevel. Science 311: 622-627.

Oberdorster G, Oberdorster E, Oberdorster J (2005) Nanotoxicology: an emerging discipline evolving from studies of ultrafine particles. Environ Health Perspect 113: 823-839.

Paoletti F, Aldinucci D, Mocali A, Caparrini A (1986). A sensitive spectrophotometric method for the determination of superoxide dismutase activity in tissue extracts. Anal Biochem 154: 538-541.

Powell MC, Kanarek MS (2006) Nanomaterial health effects - Part 1: background and current knowledge. Wisconsin Med J 105: 14-18.

Rothen-Rutishauser B, Schűrch S, Gehr P (2007) Interaction of particles with membranes. In Toxicology of particles. Donaldson K, Borm P eds, CRC, Boca Raton FL.

Sagai M, Saito H, Ichinose T, Kodama M, Mori J (1993) Biological effects of diesel exhaust particles. I. In vitro production of superoxide and in vivo toxicity in mouse. Free Radic Biol Med 14, 37-47.

Sevilla M, Valdés-Solis T, Tartaj P, Fuentes AB (2009) Fabrication of mesoporous $\mathrm{SiO}(2)-\mathrm{C}-\mathrm{Fe}(3) \mathrm{O}(4) /$ gamma $\mathrm{Fe}(2) \mathrm{O}(3)$ and $\mathrm{SiO}(2)-\mathrm{C}-$ Fe magnetic composites. I Colloid Interface Sci 40: 230-236.

Shukla R, Bansal V, Chaudhary M, Basu A, Bhonde RR, Sastry M (2005) Biocompatibility of gold nanoparticles and their endocytotic fate inside the cellular compartment: a microscopic overview. Langmuir 21: 10644-106654.

Stearns R, Paulauskis JD, Godleski JJ (2001) Endocytosis of ultrafine particles by A549 cells. Am J Respir Cell Mol Biol 24: 108-115.

Valko M, Rhodes CJ, Moncol J, Izakovic M, Mazur M (2006) Free radicals, metals and antioxidants in oxidative stress-induced cancer. Chem Biol Interactions 160: 1-40.

Yang H, Liu C, Yang D, Zhang H, Xi Z (2009) Comparative study of toxicity, oxidative stress and genotoxicity induced by four typical nanomaterials: the role of particle size, shape and composition. $J$ Appl Toxicol 29: 69-78.

Yano E, Yokoyama Y, Higashi H, Nishii S, Maeda K, Koizumi A (1990) Health effects of volcanic ash: a repeat study. Arch Environ Health 45: 367-373.

Wang L, Nagesha DK, Selvarasah S, Dokmeci MR, Carrier RL (2008) Toxicity of CdSe nanoparticles in Caco-2 cell culture. J Nanobiotech 6: 11 . 